\title{
Improving High School and Vocational School Teachers in Writing Skill
}

\author{
Awang Surya ${ }^{1}$, Firmansyah Azharul ${ }^{1}$, Wilarso ${ }^{1 *}$, Mustopa Idris ${ }^{2}$, Yusril Zindar \\ Azziqi ${ }^{1}$, Iwung Hari Retno ${ }^{1}$ \\ ${ }^{1}$ Department of Mechanical Engineering, Sekolah Tinggi Teknologi Muhammadiyah Cileungsi, Bogor, \\ Indonesia \\ 2Department of Industrial Engineering, Sekolah Tinggi Teknologi Muhammadiyah Cileungsi, Bogor, \\ Indonesia \\ *Corresponding author: wilarso@sttmcileungsi.ac.id
}

\section{ARTICLE INFO}

\section{Article history}

Received May 2, 2020

Revised May 26, 2020

Accepted May 26, 2020

Available Online May 31, 2020

Keywords

Writing Method

Writing Technique

Teaching Activity

\begin{abstract}
Sekolah Tinggi Teknologi Muhammadiyah Cileungsi has the duty of the College Dharma Chess which includes education and teaching activities, research and community service, and AIKA and Al-Islam. The purpose of this research is to teach writing methods to teachers, to facilitate teaching and learning. The method used in this research are identification of the problem, conduct a field survey, finding material, and direct training to representatives of each high school / vocational school teachers. In this training participants were given the easiest writing method. From telling great writers in life in the world, where they can exist in writing. Then the participants were asked to write an article to get used to writing. After the end of the activity, participants are asked to share in the group or discuss directly with the speaker, so that the writing that has been made can be immediately reviewed. Solutions in writing training, taking the time to write, and frequent discussions with people who often write. The result of this research is the teachers know writing techniques to develop teaching activity in the classroom.
\end{abstract}

\section{Introduction}

Cileungsi District is located in Bogor Regency, East Bogor. This small town is adjacent to Bekasi City, East Jakarta, Depok. The number of upper secondary education institutions in Cileungsi District is approximately 36, namely SMA and SMK. The schools consist of various majors, from a pharmacy, tourism, computers, and others. There are several universities in Cileungsi, including the Muhammadiyah Cileungsi College of Technology. The location of the STTMC is quite strategic because, in an area surrounded by industry or high school / vocational high school, it has the potential for human resource development in the STTMC environment. 


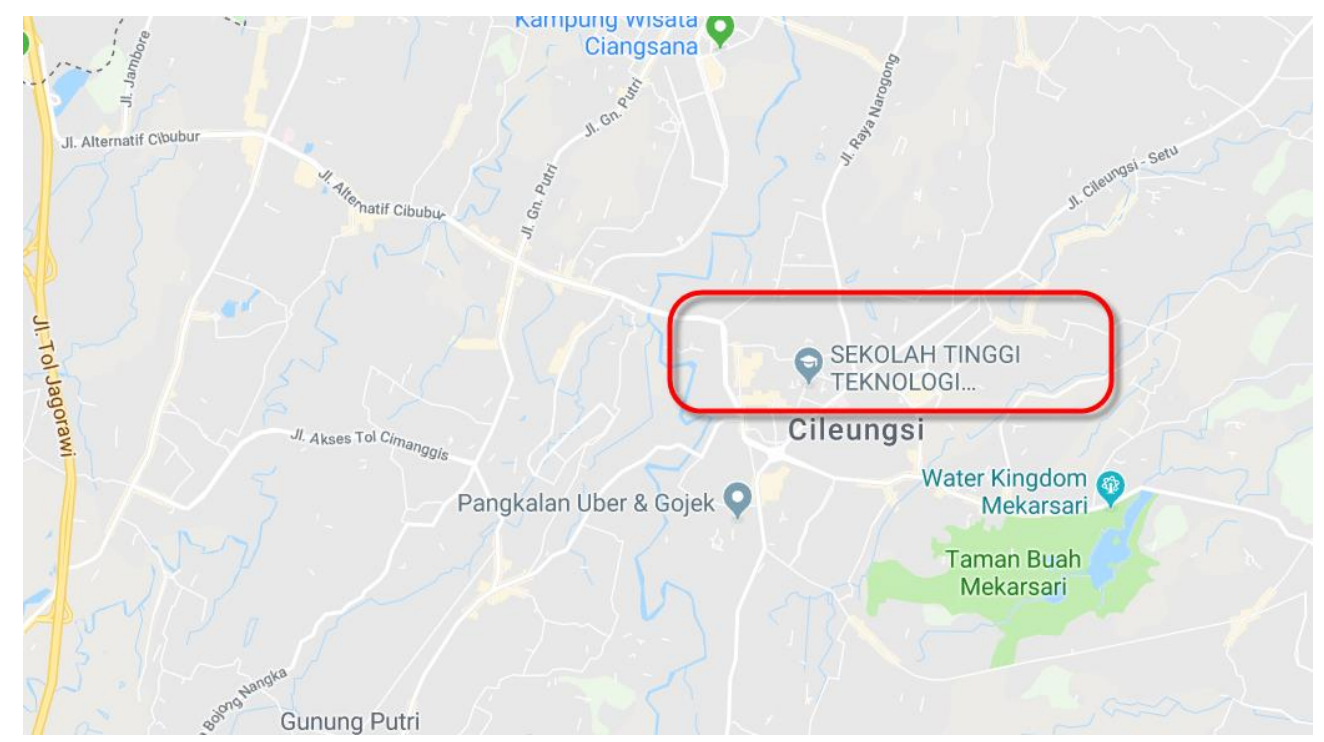

Figure 1. Training location at STT Muhammadiyah Cileungsi.

The condition of schools in the district of Cileungsi needs guidance and direction [1] to increase human resources [2]. Some things to consider include:

1. The education level of Senior High School (SMA and SMK) is a very strategic level of education [3]. At this level students must determine the next step of life which is very important, that is, they will go to tertiary education to get a bachelor's degree or take a polytechnic-level education, or even some will immediately work.

2. At this level of education the age of vocational students is in adolescence. In adolescence, someone is still emotionally unstable [4]. They are easily influenced by the environment. Of course, at this level, a teacher is highly demanded to be a creative person [5]. Without it the class will be tedious. In turn, there will be many students who are lazy to go to class and prefer to play truant and spend time outside [6].

3. School classrooms today are more often tedious and unattractive [7]. No wonder many students find uniforms outside the school during school hours. They hang out in various places without clear activities. And of course this allows some unwanted cases to occur.

4. According to official data in the District of Cileungsi, there are 36 educational institutions at the level of senior high school, both high school and vocational school. Of course there are very many students currently studying at this level. Handling and managing vocational high schools [1] interesting to be very crucial in this regard. The demand for teachers who have problem-solving skills is very important [8].

5. As fellow educators living in the district of Cileungsi District, we are moved to participate in thinking of solutions in dealing with this problem. In this case, it is provide skills and knowledge that can enhance creativity [9] and problem-solving skills for teachers in these senior high schools [10]. The proposed form of activity is improving high school and vocational school teachers in writing skill. 
Changes in the direction of vocational education development policies must be from the Vocational High Schools in increasing teaching staff. The high enthusiasm of students to attend school in the Regency in preparing facilities and infrastructure as well as competent educators, so that alignments in the management and development of Vocational High Schools are not institutions nor are they optimal and professional in the implementation [1].

In the training activities, participants are initially asked to introduce themselves so that each other knows and attempts to break the ice [11], and makes it more relaxed and relaxed. Next, participants are asked to make a personal vision and mission. The importance of this vision and mission for participants, so that participants remember the direction of their lives and their relevance to the ability to write.

This training was opened by the Chairperson of STTMC. On that occasion he gave a message so that participants were more active in writing. This is intended to develop teaching and learning processes that are easily understood by students in school. Of course this is not easy to start writing and developing the teacher's potential. Most teachers are quieter after teaching. This shows that the low interest of a teacher to be more creative at work.

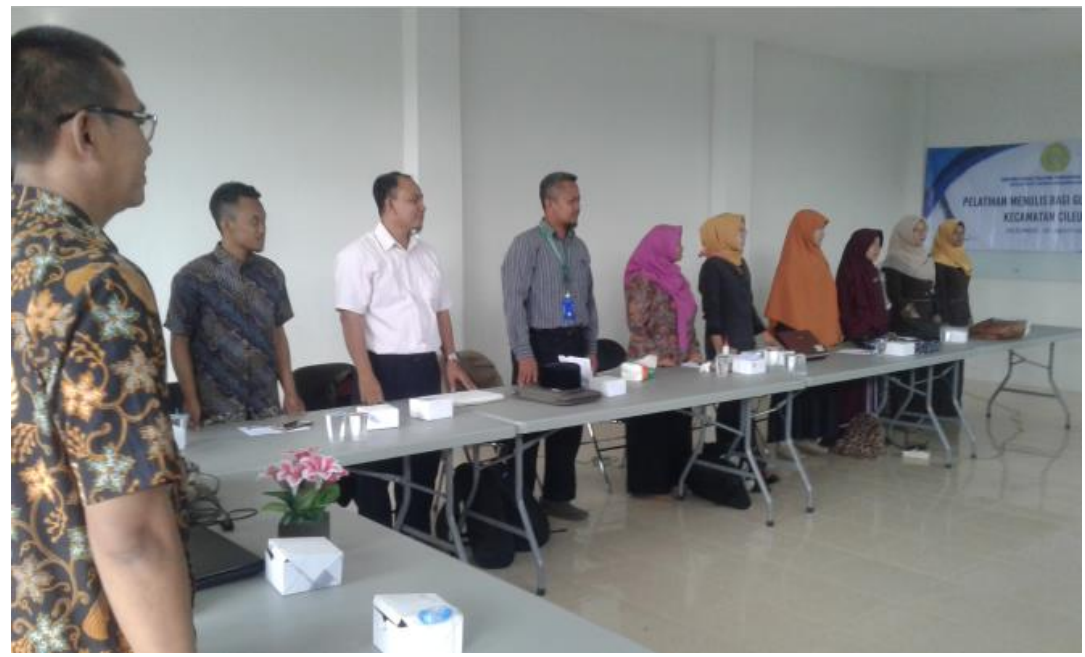

Figure 2. Participants introduce themselves before the activity begins.

This strategy is carried out by 3 activities, including procurement, Maintenance, Training, and Development. Writing training activities are part of vocational/high school teacher training and development [12].

\section{Methods}

To achieve the goals that have been previously formulated, the implementation of community service is carried out in several steps, namely:

1) Identification of the problem as a first step to formulating what will be used as material for system design and training materials in community service activities.

2) Conduct a field survey in each school as a place to carry out community service activities. Then carry out the interview process and discussion with the school in the implementation to identify problems in writing training.

3) Library research for reference material used.

4) Direct training is given to SMA / SMK teachers in the Cileungsi District 


\section{Results and Discussion}

Before the implementation of the training the community service team visited several schools to find out the desired needs in improving teacher performance. The lecturer team conducting the survey and implementation activities.

After getting input from several schools and various considerations of community service activities, it was decided that writing training for high school / vocational school teachers in the district of Cileungsi.

Community service activities are carried out by providing material and writing methods and continuing with consultation via daring. This activity was attended by 25 participants from high schools / vocational schools in Cileungsi District. During the activity, participants enthusiastically paid attention to the speaker's presentation. Participants also discussed preparing articles that would later be discussed by the speaker.

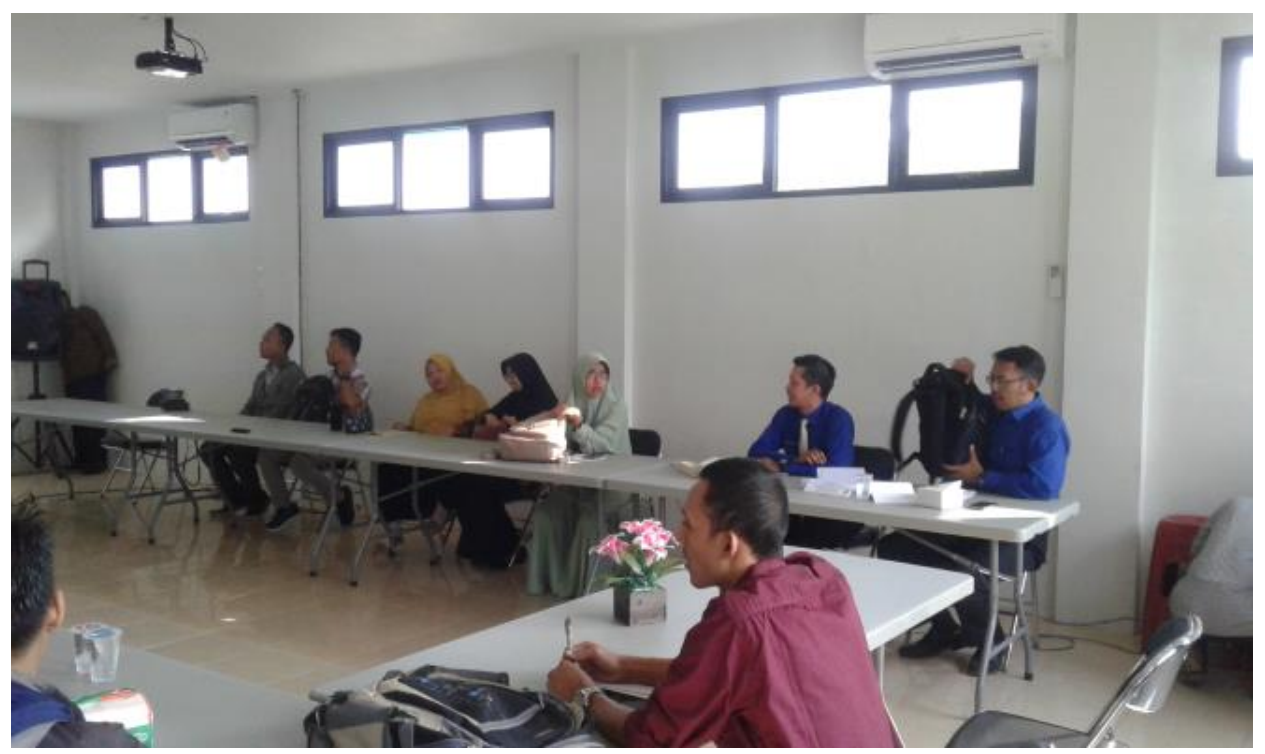

Figure 3. The atmosphere in the room in writing training. including:

In increasing literacy for all teachers and lecturers, it takes several stages, 1. Hobbies.

2. Needs.

3. Demands.

The ability to write does not depend on the profession. Farmers, employees, teachers, lecturers, bureaucrats, and others are all required to be able to write. But many think that the way it feels writing is heavy and requires genius thinking. A teacher should not experience obstacles to write because his work is mostly related to reading and writing, as well as from grammar [13].

The great scholar Imam Al-Ghazali, conveyed something valuable, 'If you are not the son of a king, and you are not the son of a great scholar. By writing, a person can be respected by the community. Thus one of the motivations [14] delivered by the speaker.

Writing skills usually develop for more than two decades when a child becomes an adult and learns composition skills through late adolescence and into early adulthood. 
Beginner writers develop from the stage of storytelling of knowledge to the level of knowledge that changes the characteristics of adult writers[15].

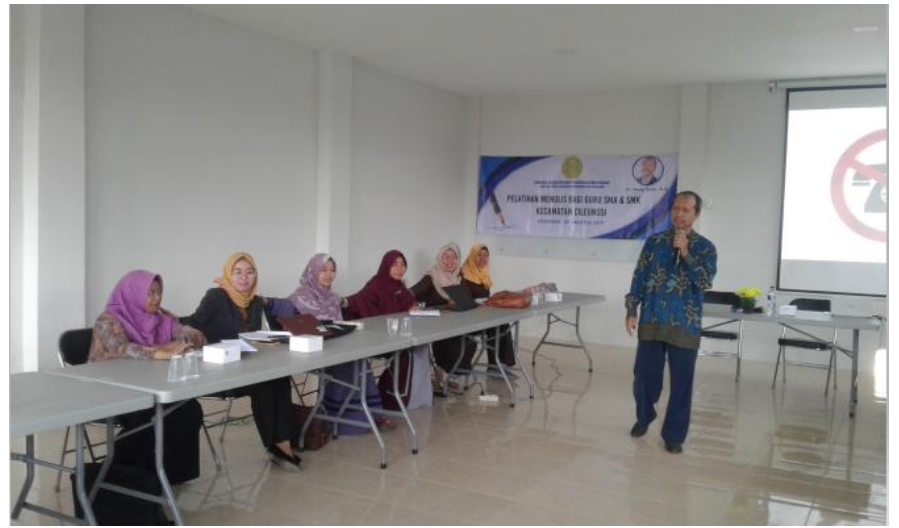

Figure 4. The speaker explains the scheme in writing.

Participant interaction with the speaker [16]. Representatives of various high school / vocational schools must explain the article that has been made to facilitate the speaker to advise in the writing.

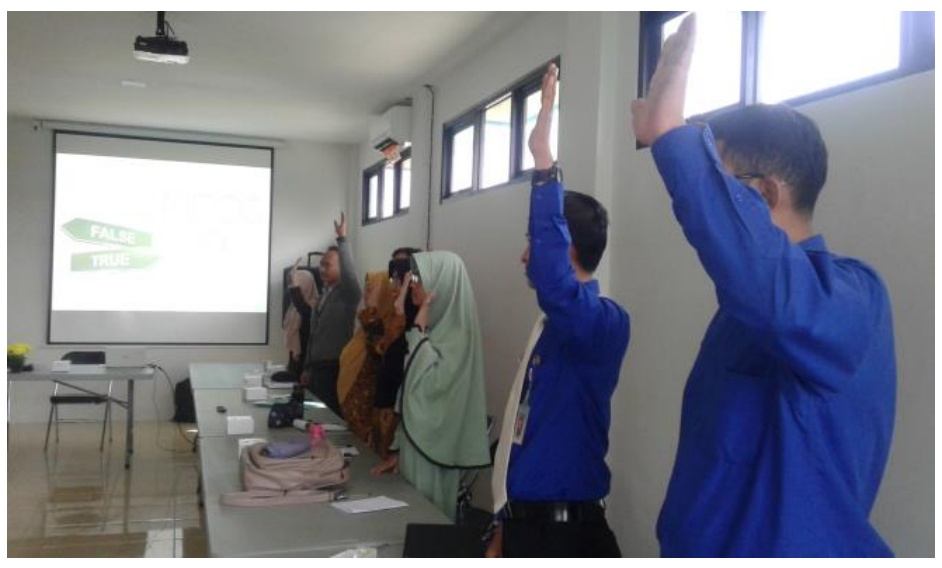

Figure 5. Gameplay for participants.

Participants was asked to come forward in front of the other participants [17], but in the presentation the participants were asked to give examples of the movement of the body, to facilitate other participants.

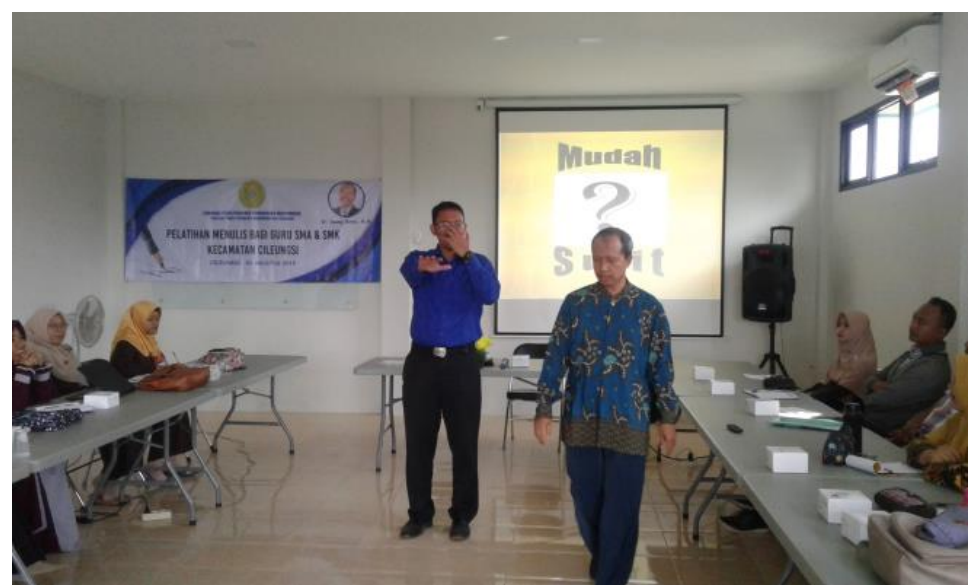

Figure 6. Participants are asked to give the game to other participants [17]. 


\subsection{Publication of Writing Activities}

Community service activities carried out by STTMC lecturers, published in Radar Bogor Newspaper, through LPPM. The published publications motivate to other lecturers [18], where lecturers must publish activities to local and national newspapers. This is a challenge for lecturers in carrying out $\mathrm{PkM}$ activities. With this publication the other participants were also pleased that the activity was well programmed and structured. Sharpen writing skills [19] SMK / SMA in the District of Cileungsi becomes something that provides motivation [20] for all teachers.

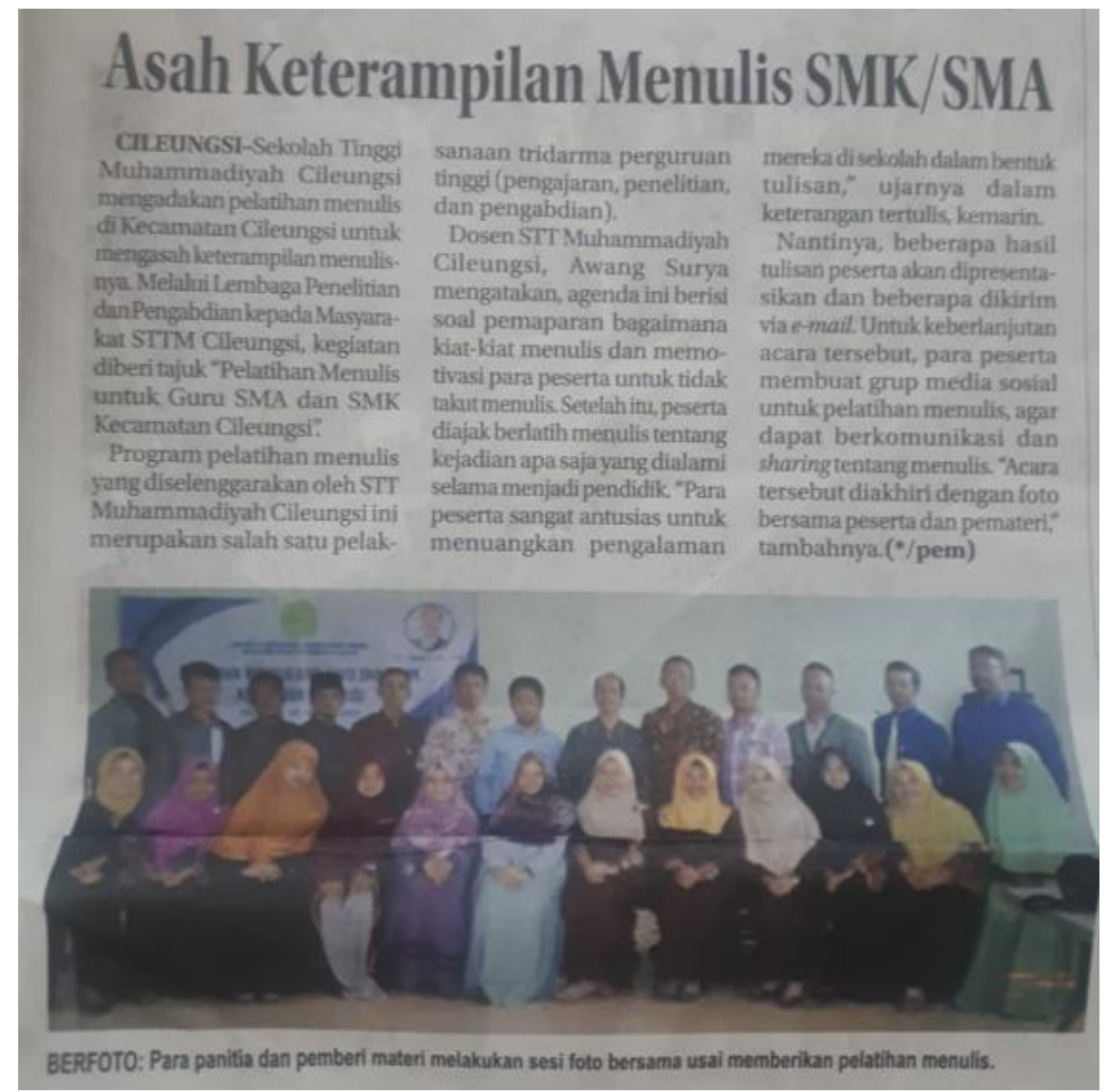

Figure 8. Publication of writing training activities to Radar Bogor.

Human resource development must be planned carefully about to the needs of its social structure [21] and national technology [22]. Find the best time to write whether [23], whether in the morning, noon, night, or early morning, spare time [24] a minimum of 30 minutes or more up to 1 hour to write. Time management is needed in writing [25].

Writing like as we talk to parents, siblings, family, coworkers, or at meetings, or others. When we talk with our interlocutors is the beginning of our writing [26], sometimes when talking to children who are toddlers or just learning to speak in a halting tone, but the purpose and purpose are the same.

Start in short sentences, which are easy to read and understand [27], every writing that is inscribed on a piece of paper or wall must be arranged neatly so that others easily understand it. Writing takes time with trial and error to produce meaningful writing [28]. 
After finishing writing following the title and contents that have been edited [29] or read by colleagues to get input, the article is emailed to the publisher for publication [30].

\section{Conclusion}

Writing initially can only be because of a hobby, if occupied will produce something useful. A teacher is required to continue to develop teaching techniques in schools. When a teacher writes and in the paper discusses learning taught by students, there is a certain satisfaction in the teacher's mind. The teaching methods delivered to students must be easy to understand and understand, with this writing making it easier to explain to students. Writing if only limited to making letters and writing on the board, something that is often done. How writing is embodied in a book is a challenge in itself. Indeed not easy. With this training, it is easier for a teacher to know writing techniques and tricks. It takes encouragement to move writing. Try and try this that must be done by a teacher, until writing is liked by everyone.

\section{Acknowledgments}

Thank you to all the high school / vocational high school teachers in Cileungsi district who participated in the writing training activities filled by the Spiritual Motivator "Awang Surya". And thank you also for the team that helped to carry out this activity.

\section{References}

[1] Z. Said, Umar, Yuswadi, Hary, Sasongko, Toha, Ahmad, \& Puspitaningtyas, "CONTRIBUTION OF VOCATIONAL HIGH SCHOOL IN IMPROVING THE QUALITY CONTRIBUTION OF VOCATIONAL HIGH SCHOOL IN IMPROVING THE QUALITY OF HUMAN RESOURCES AND THE PARTIALITY OF GOVERNMENT Umar Said, Hary Yuswadi, Sasongko, Akhmad Toha and * Zarah Puspitaningty," Int. J. Curr. Res., vol. 9, no. 11, pp. 61745-61750, 2017.

[2] A. Massora, "The effect of officer guidance in human resources quality performance," Eur. Res. Stud. J., vol. 20, no. 4, pp. 253-263, 2017.

[3] C. Tonhäuser and L. Büker, International Journal for Research in Vocational Education and Training, vol. 3, no. 2. 2016.

[4] A. Hidayat and A. Sahrudin, "Locus of Control in Late Adolescence: Characteristics and Ability of New Students To Overcome Depression," Guid. J. Ilmu Pendidikan, Psikologi, Bimbing. dan Konseling, vol. 6, no. 2, p. 172, 2016.

[5] C. L. Chiang and H. Lee, "The Effect of Project-Based Learning on Learning Motivation and Problem-Solving Ability of Vocational High School Students,” Int. J. Inf. Educ. Technol., vol. 6, no. 9, pp. 709-712, 2016.

[6] Z. Zainuddin and S. H. Halili, "Flipped classroom research and trends from different fields of study," Int. Rev. Res. Open Distance Learn., vol. 17, no. 3, pp. 313-340, 2016.

[7] M. Otukile-Mongwaketse, "Teacher centered dominated approaches: Their implications for todays inclusive classrooms," Int. J. Psychol. Couns., vol. 10, no. 2, pp. 11-21, 2018.

[8] T. Implications and P. Faculty, "Vocational Education Systems in Turkey and the World :," no. July, pp. 1-10, 2016.

[9] "Creating Effective Teaching and Learning Environments: First Results from TALIS ExECuTIvE SummARy Creating Effective Teaching and Learning Environments: First Results from TALIS," 2009.

[10] H. Retnawati, H. Dijidu, Kartianom, E. Apino, and R. D. Anazifa, "Teachers' knowledge about higherorder thinking skills and its learning strategy," Probl. Educ. 21st Century, vol. 76, no. 2, pp. 215-230, 2018.

[11] E. Biech, "Icebreakers and Introductions," 101 More Ways to Make Train. Act., pp. 41-55, 2015.

[12] U. N. 13 tahun 1992, “No Titleバイオフィードバックへのエ学的アプローチ,” Japanese Soc. Biofeedback Res., vol. 19, pp. 463-466, 1992.

[13] L. T. Tuan, "Enhancing EFL Learners 'Writing Skill via Journal Writing," vol. 3, no. 3, pp. 81-88, 2010. 
[14] A. Sari, S. Suwandi, and A. Anindyarini, "Peningkatan Motivasi Belajar Dan Keterampilan Menulis Teks Eksplanasi Kompleks Melalui Metode Kooperatif Tipe Picture and Picture Pada Siswa Smk,” J. Penelit. Bahasa, Sastra Indones. dan Pengajarannya, vol. 3, no. 3, p. 53394, 2015.

[15] R. T. Kellogg, "Training writing skills : A cognitive developmental perspective," vol. 1, no. 2008, pp. $1-26$.

[16] M. Dynel, "Participation framework underlying YouTube interaction,” J. Pragmat., vol. 73, no. March, pp. 37-52, 2014.

[17] A. Marks, "Participation Framework and Footing Shifts in an Interpreted Academic Meeting," J. Interpret., vol. 22, no. 1, p. 4, 2012.

[18] S. Munyengabe, H. Haiyan, Z. Yiyi, and S. Jiefei, "Factors and levels associated with lecturers' motivation and job satisfaction in a Chinese university," Eurasia J. Math. Sci. Technol. Educ., vol. 13, no. 10, pp. 6415-6430, 2017.

[19] A. Mark et al., "JOURNALS AND CREATIVE WRITING EXERCISES An Action research Project submitted to the Graduate Faculty of the School of Education in Partial Fulfillment of the," 2001.

[20] S. Mathew, K. Faith, and G. Edward, "Motivational Issues for Lecturers in Tertiary Institutions : A Case of Bulawayo Polytechnic," vol. 6, no. 4, pp. 167-175, 2016.

[21] B. R. Holden, V. Griggs, and B. Schaefer, "Power and Influence in the Management of Human Resource Development," Hum. Resour. Manage., 2009.

[22] P. S. Daya, "Menghadapi Era Tinggal Landas," pp. 1-10.

[23] K. Karthiga, F. Year, M. B. A. Student, and I. College, "A Study of Time Management for Students Performance," pp. 82-83, 2018.

[24] E. Gritter, "Time Management Tips for Dissertation Writing By Elizabeth Gritter, Ph.D. Visiting Scholar, UNC-Chapel Hill History Department."

[25] V. P. Jackson, "Time Management: A Realistic Approach," J. Am. Coll. Radiol., vol. 6, no. 6, pp. 434436, 2009.

[26] B. Zhang, "An Analysis of Spoken Language and Written Language and How They Affect English Language Learning and Teaching," J. Lang. Teach. Res., vol. 4, no. 4, pp. 834-838, 2013.

[27] A. A. Genlott and A. Grönlund, "Improving literacy skills through learning reading by writing: The iWTR method presented and tested," Comput. Educ., vol. 67, pp. 98-104, 2013.

[28] M. Z. Miftah, “Through Writing Process Approach,” J. English as a Foreign Lang., vol. 5, no. 1, pp. 9-24, 2015.

[29] K. Visscher and I. Management, "How to Get Your," p. 3, 2013.

1395. 